\title{
CORRELATION BETWEEN TIDES OF NORTHERN ADRIATIC SEA AND HYDRODYNAMICS OF THE KARSTIC AQUIFER IN THE POZZO DEI PROTEI DI MONFALCONE (CLASSICAL KARST)
}

\author{
KORELACIJA MED PLIMOVANJEM SEVERNEGA DELA \\ JADRANSKEGA MORJA IN HIDRODINAMIKO KRAŠKEGA \\ VODONOSNIKA V JAMI POZZO DEI PROTEI DI MONFALCONE \\ (MATIČNI KRAS)
}

\author{
Rino SEMERARO ${ }^{1}$, Federico VALENTINUZ ${ }^{2 \star} \&$ Maurizio TAVAGNUTTI $^{3}$
}

\begin{abstract}
UDC 551.466.7(262.3):556.33(450.367)

Rino Semeraro, Federico Valentinuz \& Maurizio Tavagnutti: Correlation between tides of northern Adriatic sea and hydrodynamics of the karstic aquifer in the Pozzo dei Protei di Monfalcone (Classical Karst)

The Pozzo dei Protei di Monfalcone (north - east Italy) is a cavity developed in Cretaceous limestones (Cenomanian-Turonian) situated near the contact of the north-western zone of the Classical Karst with the Lower Plain of the Isonzo/Soča River. At the bottom of the cave is the groundwater at an average altitude of $1.89 \mathrm{~m}$ a.s.l. In consideration of the proximity of the cave with the Adriatic Sea, the possible effects of the tides on the karst aquifer were investigated monitoring groundwater level, electrical conductivity $\left(\mathrm{EC}, \mathrm{K}_{25}\right)$ and water temperature using a CTD diver. Groundwater level daily oscillations show a lag of 4-4.5 hours compared to tides. The electrical conductivity variations that can be correlated to tides are $2-5 \mu \mathrm{S} / \mathrm{cm}$. Excluding that the cave, given the altimetry, is directly affected by the saltwater wedge, the cyclical variations of the $\mathrm{EC}$ would derive from the dispersion at the salt water and fresh water interface and from the mobilization of more mineralized water coming from the rock mass. The hypothesis of mixing fresh and salt water and saline fossil waters in the caves of the area has been verified by a general increase in the chloride ion in this area of the karst aquifer compared to the internal areas of Classical Karst.

Key words: Sea tides, Hydrogeology, Groundwater monitoring, Classical Karst, Adriatic Sea, Italy.
\end{abstract}

Izvleček UDK 551.466.7(262.3):556.33(450.367)

Rino Semeraro, Federico Valentinuz \& Maurizio Tavagnutti: Korelacija med plimovanjem severnega dela Jadranskega morja in hidrodinamiko kraškega vodonosnika v jami Pozzo dei Protei di Monfalcone (matični kras)

Pozzo dei Protei di Monfalcone (severovzhodna Italija) je jama, razvita v krednih apnencih (cenomanij-turonij) v bližini stika med severozahodnim delom matičnega krasa in spodnjo soško nižino. Na dnu jame je podzemna voda na povprečni višini 1,89 $\mathrm{m}$ n. m. Ker je jama v bližini Jadranskega morja, so bili možni vplivi plimovanja na kraški vodonosnik proučevani na podlagi merjenja nivojev, specifične električne prevodnosti $\left(\mathrm{EC}, \mathrm{K}_{25}\right)$ in temperature podzemne vode $\mathrm{z}$ uporabo samodejnih merilnikov s shranjevanjem podatkov. Dnevna nihanja nivojev podzemne vode kažejo zaostanek 4-4.5 ure za plimovanjem. S plimovanjem povezane spremembe specifične električne prevodnosti so $2-5 \mu \mathrm{S} / \mathrm{cm}$. Ker lahko glede na razmerje višin izključimo neposreden vpliv klina morske vode, lahko ciklične spremembe EC razlagamo $\mathrm{z}$ disperzijo na stiku slane in sladke vode ter $\mathrm{z}$ mobilizacijo bolj mineralizirane vode iz kamninske osnove. Hipoteza mešanja sladke in slane vode in slanih fosilnih vod $\mathrm{v}$ jamah tega območja je bila potrjena s splošnim povišanjem koncentracij kloridnega iona $\mathrm{v}$ tem delu kraškega vodonosnika $\mathrm{v}$ primerjavi z notranjimi deli matičnega krasa.

Ključne besede: plimovanje, hidrogeologija, monitoring podzemne vode, matični kras, Jadransko morje, Italija.

\footnotetext{
${ }^{1}$ Rino Semeraro, Via Rotta, 6 -34170 Gorizia, Italy, e-mail: rinosemeraro0@gmail.com

${ }^{2}$ Federico Valentinuz ${ }^{*}$ Professional Geologist - Centre for Karst Research “C. Seppenhofer”, Via Dante, 25/C1-34071 Cormons, Italy, e-mail: geo.valentinuz@gmail.com

${ }^{3}$ Maurizio Tavagnutti, Centre for Karst Research “C. Seppenhofer”, Via Ascoli, 7-34070 Gorizia, Italy, e-mail: mauriziotavagnutti@ gmail.com

* Corresponding author
}

Received/Prejeto: 04.06.2019

DOI: 10.3986/ac.v49i1.8966 


\section{INTRODUCTION}

In the north-western part of the Classical Karst, near the contact with the Quaternary sediments of the plain, the Pozzo dei Protei di Monfalcone (4383/VG5403 caves cadastre) develops (Fig. 1). The shaft is located in the railway station of Monfalcone (Gorizia, Italy, WGS84 latitude $45^{\circ} 48^{\prime} 28.3623^{\prime \prime}$ and longitude $\left.13^{\circ} 32^{\prime} 34.8179^{\prime \prime}\right)$. Entrance is at $23.18 \mathrm{~m}$ a.s.l, the depth to the bottom of the underground lake is $23.71 \mathrm{~m}$ while the maximum length at the bottom is $6 \mathrm{~m}$. The total depth from the top of the shaft to the bottom is $25.71 \mathrm{~m}$. The groundwater level is about $2.5 \mathrm{~m}$ above the bottom of the cavity at an average altitude of $1.89 \mathrm{~m}$ a.s.1.. $4.4 \mathrm{~km}$ southeast there are the Timavo Springs (Fig. 1) while $750 \mathrm{~m}$ to the south there is the Valentinis Canal (Figs. 1-2). This artificial canal receives water from the Isonzo/Soča River (Fig. 1) and in Monfalcone flows into the Gulf of Trieste (Panzano Bay). Monfalcone area forms the southeastern end of the Friuli Plain.

The Pozzo dei Protei di Monfalcone is so called because in the perennial water basin on the bottom live numerous Proteus anguinus s.l. Laurenti, 1768. The Proteus anguinus has been observed in this cave since its discovery in 1987. In the area of the Timavo River springs and in the north-western part of the Classical Karst, also called the "Karst of Isonzo", its presence is capillary and consistent (Stoch 2017), with exclusion in anchialine ecosystems.

The area of the Pozzo dei Protei di Monfalcone from the hydrological point of view is little known. The various syntheses on the hydrogeology of the Classical Karst (Civita et al. 1995; Ballarin et al. 2000a, 2000b; Cucchi et al. 2000a, 2015; Grillo 2012) consider above all the great karst circuit of the subterranean Timavo River, the karst groundwater in the main monitoring points, the problem of the contribution of the phreatic groundwater of the Isonzo River, but not specifically the area in question, which appears marginal. Monitoring with CTD divers was conducted in several points (Cucchi et al. 1998; Grillo 2012), but never involved these marginal areas of the hydrostructure.

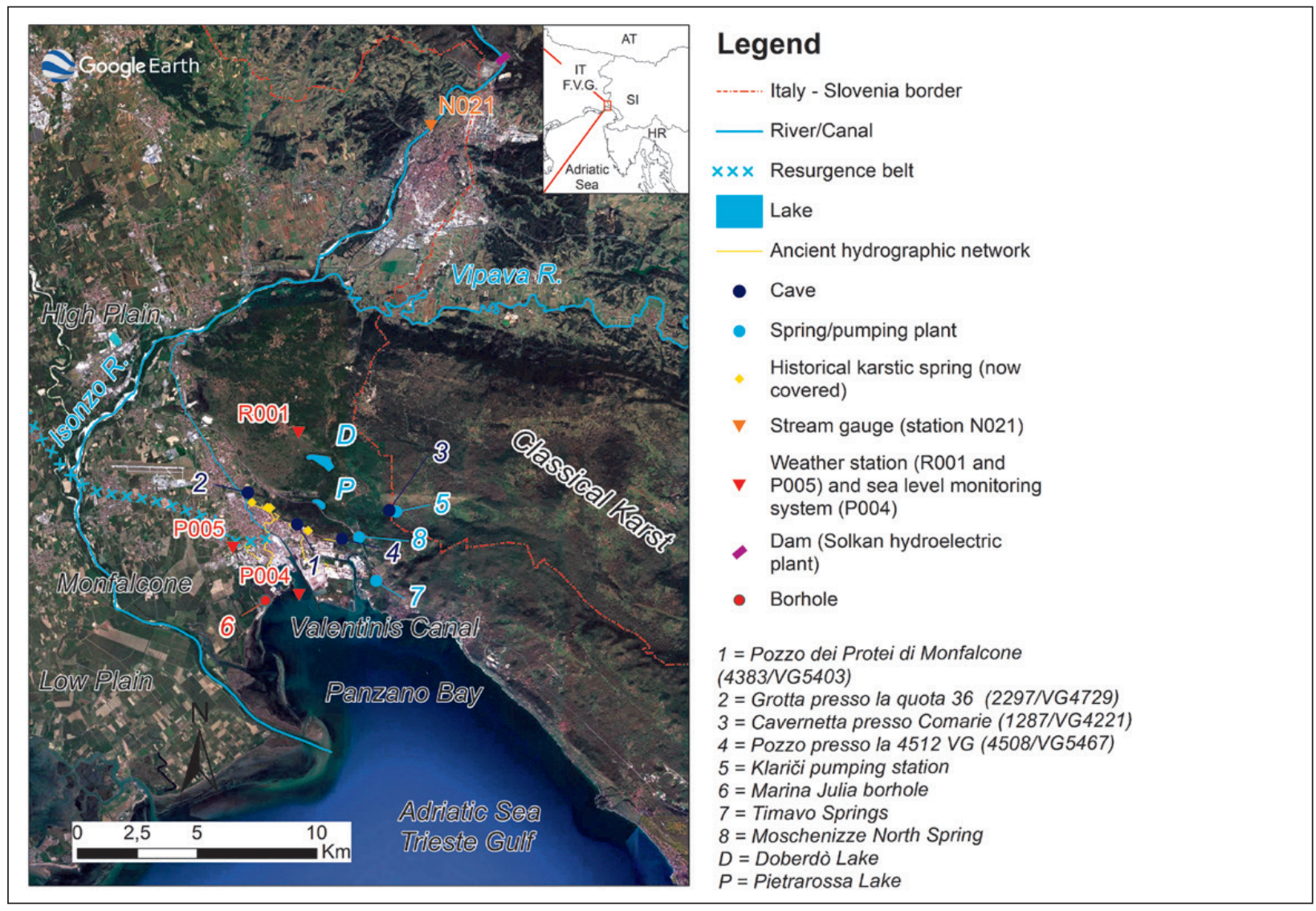

Fig. 1: Geographical setting and meteorological and hydrographic stations considered in this study: "R001 Doberdò Gradina visitor center", "P004 Panzano marigraph", "P005 Monfalcone city pool", "N021 Piuma bridge" (Gorizia), hydrometer and flow measurement station (Codes of Regione Autonoma Friuli Venezia Giulia). 
The effects of tides on coastal or near-shore karst aquifers are fairly well known, but in detail they have not been studied in many parts of the world.

Generally, the EC of the karst groundwater varies according to the oscillations in the water table compared with the sea level, and not in relation to the absolute load of the same aquifer. Among the common effects, in addition to the oscillations of salinity in the transition zone between freshwater and saltwater, there are small variations of electrical conductivity in the shallow phreatic zone of the karst aquifer. The different effects of sea level oscillations on groundwater levels in relation to distance from the coast and the local hydrogeological parameters entail a continuous change in the piezometric surface of the water table (Cotecchia \& Scuro 2010; Cuello et al. 2017; Zamora et al. 2017; Collignon 2019).
Sea tides influence on groundwater levels of the western part of Classical Karst hydrostructure was sporadically observed in several points (Nicolettis 1983; Samez et al. 2005; Federazione Speleologica Isontina 2011), as well as the presence of typical salt water chemical species (e.g., $\mathrm{Cl}^{-}, \mathrm{SO}_{4}{ }^{2-}$ ) (Gemiti 2011), but nowadays a sea water intrusion model does not exist.

To verify the possible correlations with the tides of the high Adriatic Sea a CTD-Diver probe from Eijkelkamp (Netherlands) was installed in the water basin of the Pozzo dei Protei di Monfalcone by the Centre for Karst Researches "C. Seppenhofer" of Gorizia (Italy). This instrument recorded level, temperature and electrical conductivity variations.

\section{HYDROGEOLOGICAL CHARACTERISTICS OF THE AREA AND THE SHAFT}

The Classical karst, in the northwesternmost part of the External Dinarides, forms an SE-NW oriented anticlinorium (Placer 2008, 2015) dissected by numerous strike-slip faults having a Dinaric direction. The western border of the Classical Karst facing the Gulf of Trieste is characterized by the Dinaric frontal ramp system, constituted by the NW-SE segments of the Palmanova line connected towards the south to the Črni Kal thrust and by the Karst thrust (Placer et al. 2010; Carulli 2011). The carbonate platform's outcropping rocks, are between the Valanginian-Aptian and the Eocene ages, at the top there is the Flysch (Eocene) (Jurkovšek et al. 2016).

The Pozzo dei Protei di Monfalcone (Fig. 2; Fig. 4) is developed on the forelimb of the fold in the Repen formation (Cenomanian-Turonian), locally represented by bioclastic and partially recrystallized stratified limestones (Jurkovšek et al. 1996, 2016). These are gray to dark-gray limestone in decimetric strata. Bedding planes dip direction is around SSW, while dip is $10^{\circ}-40^{\circ}$. Strata dip variations are due to faults or accentuation of the main fold.

On site, statistically, 4 main joint systems were identified, named $\mathrm{j} 1$ on average between N-S and NNESSW, J2 average NE-SW, $\mathrm{j} 3$ average E- $\mathrm{W}, \mathrm{j} 4$ average ESEWNW/SE-NW, they comply with the studied by Venzo \& Fuganti (1965) and Merlak (1972) and linked to the kinematic model already identified by those Authors (Fig. 3). They are predominantly sub-vertical joint systems. To the south of the shaft, a probably ESE/WNW subvertical transcurrent fault is hypothesized (Jurkovšek et al. 2016) (Fig. 2; Fig. 4). In the south, there are the limestone of the
Sežana formation (Turonian p.p.-Campanian p.p.) generally represented by biomicrites in normally decimetric layers, generally high karstified, buried by Quaternary and marine sediments. The limestone of Sežana formation crops from the continental and marine Quaternary sediments $2 \mathrm{~km}$ SE of the Pozzo dei Protei di Monfalcone, forming the two small hills (Insulae Clarae) of the Roman Baths, where there are thermal water emergencies (Petrini et al. 2013) from a carbonate reservoir deep through the fault system of the Palmanova Line. The Palmanova SE-NW line, south of Monfalcone, has been identified with offshore geophysics. According to the geostructural interpretation of Carulli (2011), the Gulf of Trieste would be a Graben and the area of Monfalcone located at the north-western border.

About $1 \mathrm{~km}$ south of the Pozzo dei Protei di Monfalcone the Karst thrust is buried, and it is linked, more to the south, by the Palmanova line (Busetti et al. 2010a) buried by marine sediments (Nicolich et al. 2004). In the area, these are also called Dinaric thrusts of the Panzano line (Busetti et al. 2010b).

Not far from the Pozzo dei Protei di Monfalcone, to $\mathrm{N}$ there is the stratigraphic contact with the Povir formation (Albian p.p.-Cenomanian p.p.) which, in the area, is marked by a long outcrop of Komen limestones (Albian p.p-Campanian p.p) consisting in platy and laminated limestones with chert placed at the top of a predominantly dolomitic succession. It is known that Komen limestone is a lithofacies with a low epigean karstifiability. The upper part of the Povir formation, mainly dolomitic, in this area is characterized by a succession of 


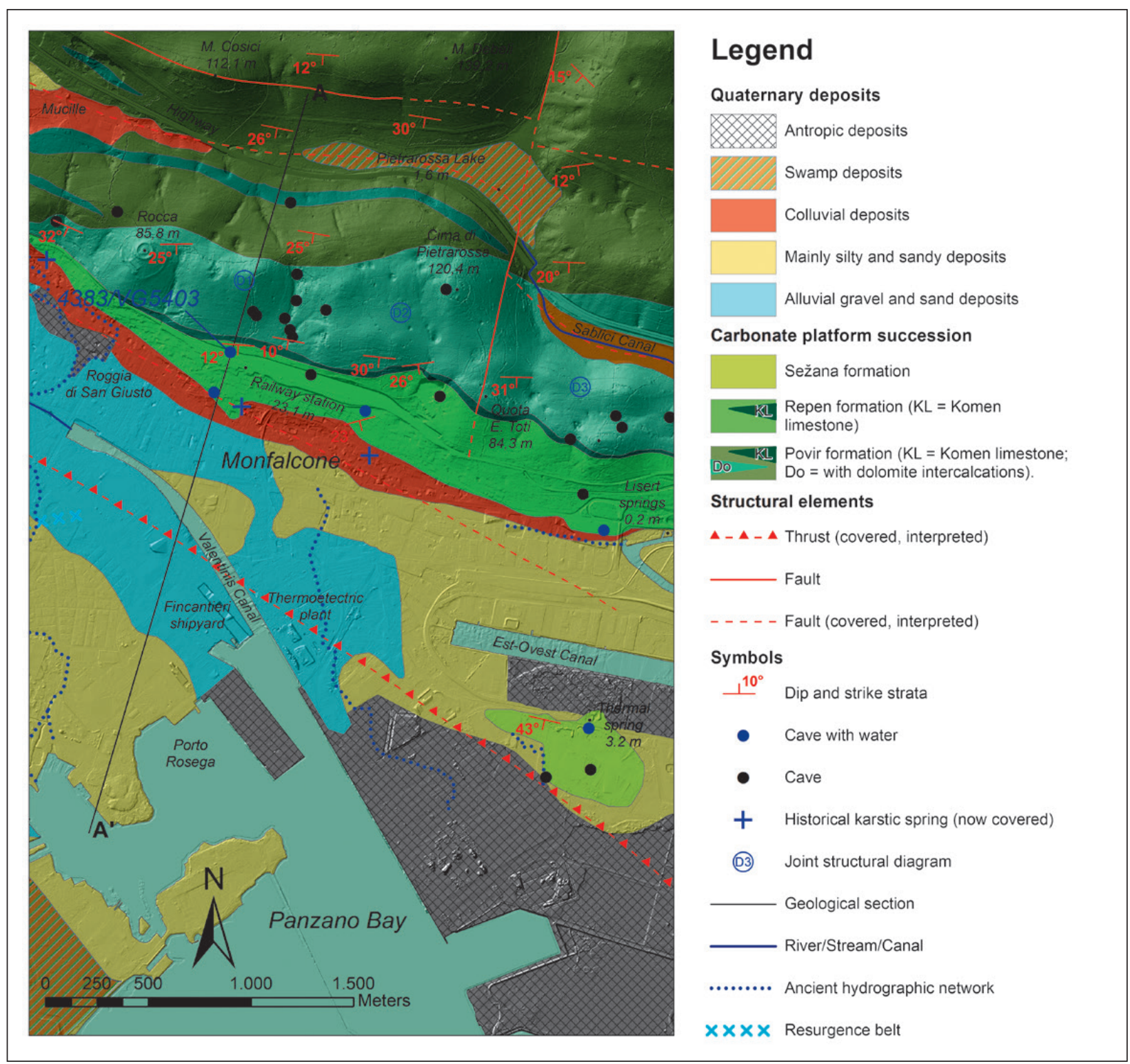

Fig. 2: Geological map of the area.

dolomite breccias alternating with platy limestone, gray limestones, dolomitic limestone interspersed with platy limestone, crystalline dolomites alternating with blackish limestone. The dolomitic member of Povir formation shows an interesting underground phenomenon represented by karstic shafts (Cancian 1976), demonstrating how the same lithofacies that in outcrop are characterized by a low-grade of karstifiability in depth can be formed a high frequency of karst phenomena where the subterranean drainage is concentrated. The karst area extending to the north of the Pozzo dei Protei di Monfalcone, characterized by Povir formation, with the open polje of Pietrarossa and Mucille, up to the polje of the Doberdò Lake, is crossed by already known faults with a dinaric and anti-dinaric trend (Martinis 1962) that tectonically conditioned these karst depressions.

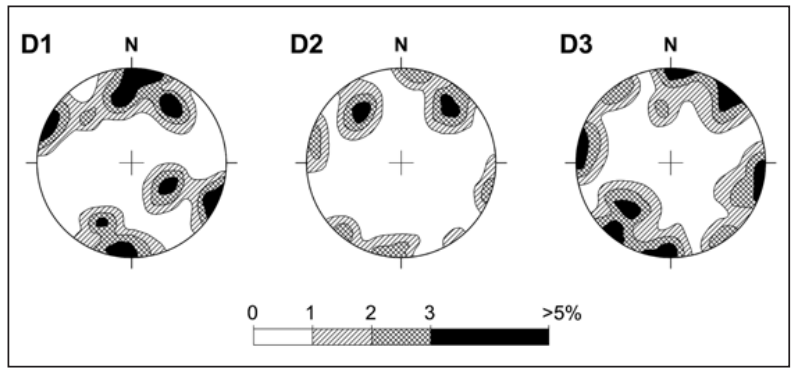

Fig. 3: Structural diagrams of the rock joints; Schmidt net inferior hemisphere. 100 poles each diagram. Location marked on Fig. 2. 


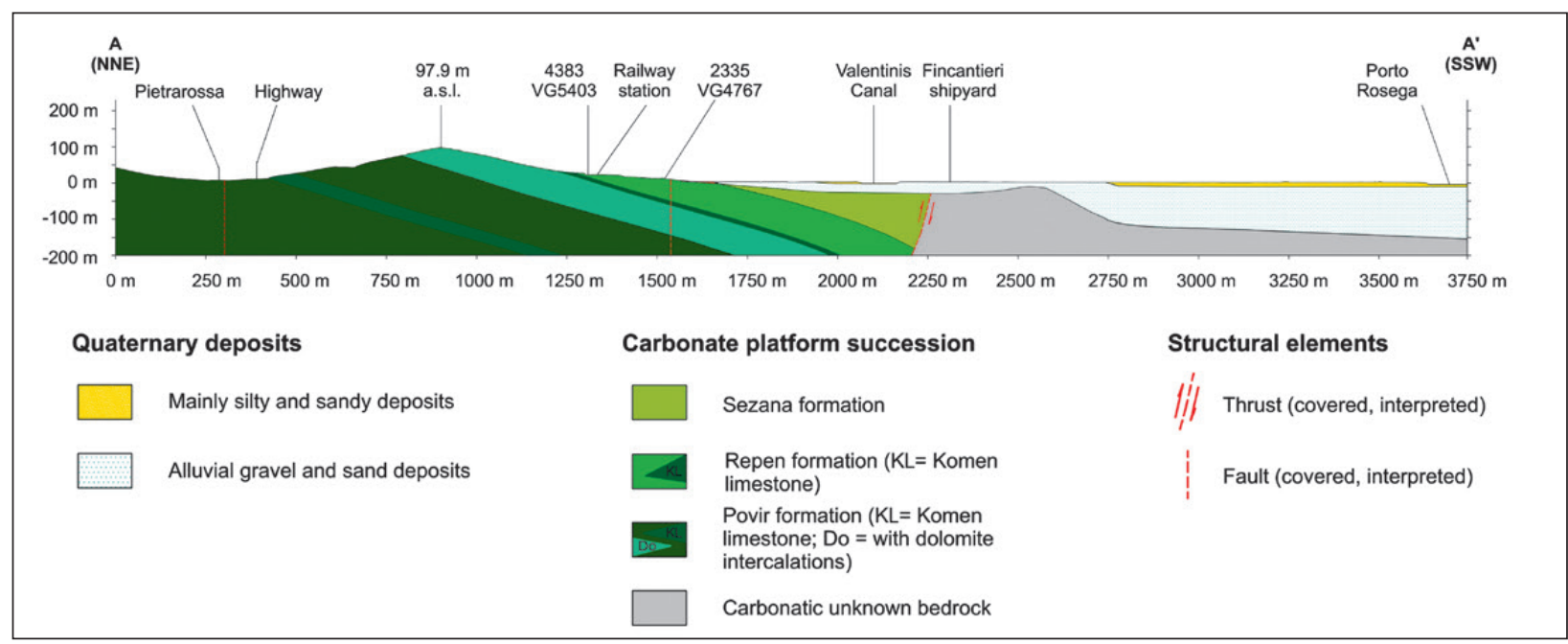

Fig. 4: Geological section A-A'.

\section{THE BEDROCK AND THE QUATERNARY}

The carbonate lithotypes of the karst plateau plunge below the sediments of the plain. The shape of the bedrock of the SW area of the railway station can be defined as a probable buried valley with an SSE/NNW axis. This probable paleovalley (Mosetti 1957) is bordered by a rise that forms the limestone outcrop of the hills of the Roman Baths. The rise develops in the dinaric direction towards the thermoelectric plant and the shipyard where the limestones are, respectively, at depths less than $30 \mathrm{~m}$ and slightly less than $10 \mathrm{~m}$, while at the center of the paleovalley the limestone rock is found at a depth of 30-40 m (Menchini 2016). At SW of the ridge the bedrock deepens and reaches, in a few hundred meters, depths greater than $100 \mathrm{~m}$ from the surface, suggesting not only erosive but above all tectonic causes (Fig. 4).

This is evidenced by a borehole in Marina Julia, about $3.5 \mathrm{~km}$ SSW of the Karst edge (Fig. 1), where the bedrock is located at the depth of $197 \mathrm{~m}$ and consists of the marly-arenaceous Eocene Flysch (Regione Autonoma Friuli Venezia Giulia 1990).

The Monfalcone alluvial plain is divided into two sectors by the resurgence belt. The northern part is known as the "High Plain" while in the south it is known as "Low Plain". The latter is characterized by alternating levels with low hydraulic conductivity (confining beds) and high hydraulic conductivity (aquifers).

The quaternary deposits that form the plain are mainly represented by alluvial deposits of the Grado Unit, Subunit of Aquileia, 10,000 years BP, IV century AD (Regione Autonoma Friuli Venezia Giulia, Servizio Geologico 2008; Calligaris et al. 2017). The Lisert area, located in the East, in Roman times, was occupied by a vast lagoon (e.g., Insulae Clarae, Lacus Timavi) progressively filled with sandyclay and alluvial sediments (Marocco \& Melis 2009).

The Karst plateau is bordered by silty-clay eluviocolluvial sediment (red soils, Terra rossa) while the depression of the karst lake of Pietrarossa is filled by organic silts.

Many sectors of the urbanized area (harbor and industrial area) are covered by anthropic materials.

In the SW area of the ridge that borders the Karst plateau, below the alluvial sediments of the Sub-unit of Aquileia, gravel and sand alternates with clay layers that have thicknesses of more than $10 \mathrm{~m}(17.8 \mathrm{~m}$ ) (Regione Autonoma Friuli Venezia Giulia 1990; Menchini 2016). This is the sector of the plain crossed by the resurgence belt.

\section{GEOMORPHIC STRUCTURE OF THE SHAFT}

The carbonates of Repen formation (Cenomanian-Turonian) of Pozzo dei Protei di Monfalcone (Fig. 5) are locally represented by alternations of grey bioclastic lime- stones and dark-grey limestones with dolostones intercalated (Cancian 1976), with average thicknesses of layers of $15-35 \mathrm{~cm}$ or more. 


\section{Pozzo dei Protei di Monfalcone 4383/VG 5403}

WGS 84

latitude: $45^{\circ} 48^{\prime} 28.3623^{\prime \prime}$

longitude: $13^{\circ} 32^{\prime} 34.3179^{\prime \prime}$

$23.18 \mathrm{~m}$ a.s.1.

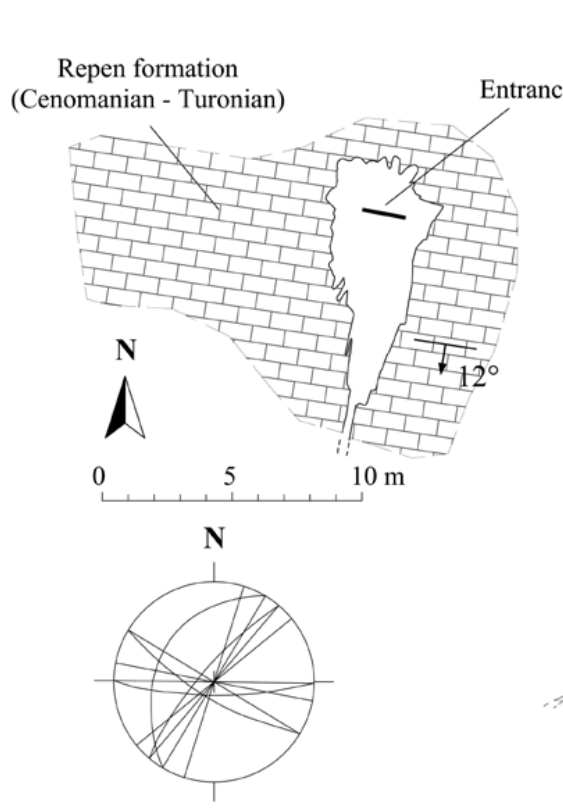

SSW

NNE

\section{Artificial} entrance

$23.18 \mathrm{~m}$ a.s.1.

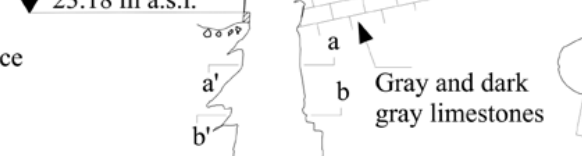

a
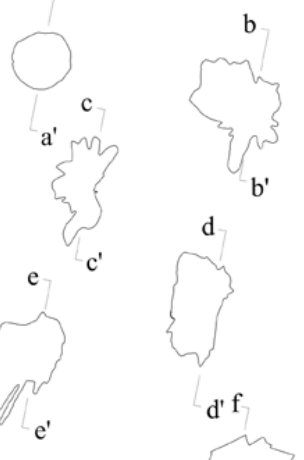

d
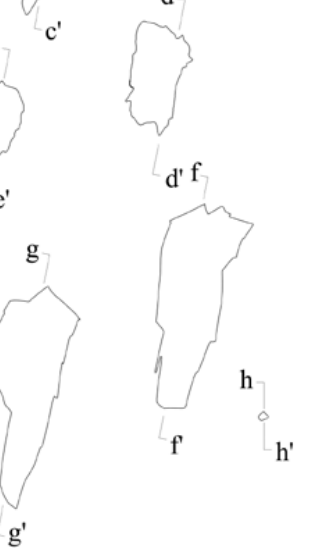

Fig. 5: Profile, map, and cross-sections of Pozzo dei Protei di Monfalcone - a) greats circles of main joints on Schmidt net inferior hemisphere.

The shaft is located in the hinge area of a small synform fold with anti-dinaric axis. It could be hypothesized that in the vadose phase the slow water flow occurred along the layers in the depression zone of rocky mass. The vertical structure of the Pozzo dei Protei di Monfalcone is developed on joints of set $j 1$. The shaft has an axis NNE-SSW, corresponding to the large joints that characterize it. It is a system of shear joints that corresponds to that of the antithetic faults of the Pietrarossa fault (Masoli \& Spangher 1977) weakly transcurrent (direction j4) located about 1,200 meters to the north. This characteristic is maintained from about 5 meters below its roof to the bottom. In the phreatic part, the diving exploration (Russo 2018) has identified an impracticable conduct with a triangular section of about $30 \times 30 \mathrm{~cm}$, developed along a NNE-SSW joint.

\section{HYDROLOGY OF THE KARST AREA}

Classical Karst's carbonatic units host an aquifer which receives inputs from autogenic recharge from the rainfalls, and from the allogenic input from Reka/Timavo River which sink at the Škocianske jame (located in Slovenia, more than $30 \mathrm{~km}$ south east from Monfalcone) and from Isonzo/Soča-Vipacco/Vipava rivers.
Monfalcone Area's cumulative annual rainfalls in the period 2006 - 2019 oscillated between $1875 \mathrm{~mm}$ and $854 \mathrm{~mm}$, with the maximum amount of precipitations usually registered in spring and late autumn (OSMER FVG 2019a). Annual mean temperature in the area is about $14.5^{\circ} \mathrm{C}$ (OSMER FVG 2019b). 
The main outflow of the Classical Karst aquifer is located in SE of the Pozzo dei Protei di Monfalcone and the distinction between the karst underground water infiltrating from the basin, infiltration from the phreatic groundwater of the Isonzo River and those coming from the Reka/Timavo River, is relatively easy based on their geochemical characterization (Cancian 1988; Doctor et al. 2006). In Timavo springs area there are several springs including two karstic lakes (Doberdò and Pietrarossa lakes).

A recent tracer test (Cavanna 2018) injecting in the sinkhole of the Doberdò Lake (karst lake located about $3 \mathrm{~km}$ to the NNE del Pozzo dei Protei di Monfalcone) showed a dispersion of the waters in the SE direction towards the springs of Sablici, Moschenizze and Timavo, including the Cavernetta presso Comarie (1287/ VG4221), with positive traces in the area of the wells of karst water supply of Klariči where the water is mainly coming from the Isonzo/Soča (Urbanc et al. 2012).

The karst hydrology to the north of the Pozzo dei Protei di Monfalcone is dominated by the water circulation of the closed or open poljes of the lakes of Doberdò,
Mucille and Pietrarossa (Boegan 1938; Bidovec 1965; Cucchi et al. 2000b, 2014; Gemiti \& Licciardello 1977; Samez et al. 2005), then from the relationships between superficial infiltration and the contribution of the river Vipacco and above Isonzo. In the Doberdò area, in mechanical drillings that penetrated the karst aquifer in a rocky matrix, Martinis (1975) measured with piezometers a water table slightly inclined towards south of 3\%o with fluctuations of 2-3 m. In the Doberdò Lake, where water flows in and out from normally submerged cavities, level fluctuations of over $6 \mathrm{~m}$ were recorded (Cucchi et al. 2000b).

Several springs flowed from the karstic plateau in Monfalcone area in the past. These springs, nowadays covered by the urban area, had a discharge of about 0.2 $\mathrm{m}^{3} / \mathrm{s}$ (Zini et al. 2017) and partially fed a hydrographic network of streams like Roggia di San Giusto (Degrassi 2017) that flowed seaward from the northern part of the city to the Panzano Bay/Porto Rosega (Figs. 1-2). The position of these outflows (Figs. 1-2), deduced from historical sources, is indicated in Monfalcone's geological study for the urbanistic planning (Iadarola 1996).

\section{KNOWLEDGE ON THE EFFECTS OF THE TIDES ON THE KARST AQUIFER}

The oscillations of the level of the Gulf of Trieste due to the astronomical and meteorological tide influence the piezometric level of the Classical Karst aquifer. These effects can be observed especially in areas near the coastline. According to the geo-structural setting, it is an unconfined karst aquifer, with small oscillations of the water table in the western sector of the plateau compared to the considerable thickness of the epiphreatic and saturated area (maximum amplitudes are less than ten meters).

Nicolettis (1983), studying with a tide gauge the fluctuations of the level of Doberdò Lake observed the periodic oscillations influenced by the tide of the Gulf of Trieste. According to the author the oscillations identified were regular, but having an inverse trend to the tides. The oscillations had a lag due to the propagation of the tide in an aquifer characterized by a fissured network with dispersive water circulation. Analyzing the decrease of a flood the high tides caused a decrease in the emptying rate, while during the low tides the emptying rate was maximal. These observations and hypotheses have not been confirmed in a subsequent study (Samez et al. 2005) which identified the effect of the tide only at the Pozzo dei colombi di San Giovanni di Duino (215/ VG227), a cave located a few hundred meters from the Timavo springs.
Studies performed by monitoring the fluctuations of the water level in limestone inside the boreholes for the construction of the Slovenian Karst Aqueduct near Klariči (nowadays a pumping station), about $4 \mathrm{~km}$ from the sea, have shown that they are affected by tidal oscillations with a lag. The system has been compared to that of a semi-confined aquifer, due to the deep karst and to the simultaneous presence of sub-vertical fractures in the aquifer that are in contact with the atmosphere, while maintaining in many areas a confinement in the same carbonate rocks (Krivic 1982a, b; Drogue et al. 1984).

Observations carried out on the water level in the Cavernetta di Comarie (1287/VG4221), located between the Pietrarossa Lake and Klariči, have shown that, even in this cavity, the level would be influenced by tidal oscillations (Samez et al. 2005).

In the subsoil of Monfalcone and its industrial zone there are several caves in which the influence of tidal oscillations on the groundwater level has been sporadically observed. In addition to the caves located in the Lisert area, the Grotta presso la quota 36 (2297/VG4729) water level should also be affected by the tide (Federazione Speleologia Isontina 2011). 


\section{METHOD AND INSTRUMENTS}

As knowledge of the karst hydrogeology of the area was very low, the Centre for karst researches "C. Seppenhofer" of Gorizia (Italy) (Rejc 2018; Semeraro \& Valentinuz 2018) has installed in the underground water basin at the bottom of the Pozzo dei Protei di Monfalcone (Fig. 6) a CTD-Diver D1271 probe produced by Eijkelkamp (Netherlands), coupled to a Baro-Diver probe, to record the temperature $(\mathrm{T})$, electrical conductivity $\left(\mathrm{EC}, \mathrm{K}_{25}\right)$ and water levels $(\mathrm{H})$. The technical characteristics of the CTD-Diver are the following: deep range 0-10 m, typical accuracy $\pm 0.05 \%$ full scale, long-term stability $\pm 0.2 \%$, resolution $0.2 \mathrm{~cm}$. Electrical conductivity: measuring range $0-30 \mathrm{mS} / \mathrm{cm}$ (set by the operator), accuracy $\pm 1 \%$, resolution $\pm 0.1 \%$. The range of the Baro-diver probe for measuring atmospheric pressure is $150 \mathrm{~cm}$ of water column, accuracy of $0.5 \mathrm{~cm}$ and resolution $0.1 \mathrm{~cm}$. The temperature range measured by both instruments is $-20-80$ ${ }^{\circ} \mathrm{C}$, accuracy $\pm 0.1{ }^{\circ} \mathrm{C}$, resolution $\pm 0.01^{\circ} \mathrm{C}$.

The main objective was to study the effects of tidal variations on this almost unknown sector of the karst aquifer of the Classical Karst. The monitoring lasted for 104 days, from 14/06/2018 to 25/09/2018. The measurement interval set was $30 \mathrm{~min}$.

To evaluate aquifer recharge variations, groundwater level data have been compared with Isonzo River discharge and rainfalls measured by the regional monitoring network (Regione Autonoma Friuli Venezia Giulia, 2019) kindly supplied by Hydrographic bureau of Regione Autonoma F.V.G. (Fig. 1). The Isonzo River discharges measured at the stream gauge station, located in Gorizia at Piuma bridge (regional Id code: N021), upstream of the main losses that feed alluvial plain and karst aquifer, was considered. The rainfalls measured at Doberdò Gradina visitor center meteorological station (regional Id code: R001) have been considered, too. This point is located in the western part of the Classical Karst Plateau at $134 \mathrm{~m}$ a.s.l. Monfalcone city pool station have been chosen to compare cave temperatures with atmospheric temperatures due to its location in the Monfalcone plain and its

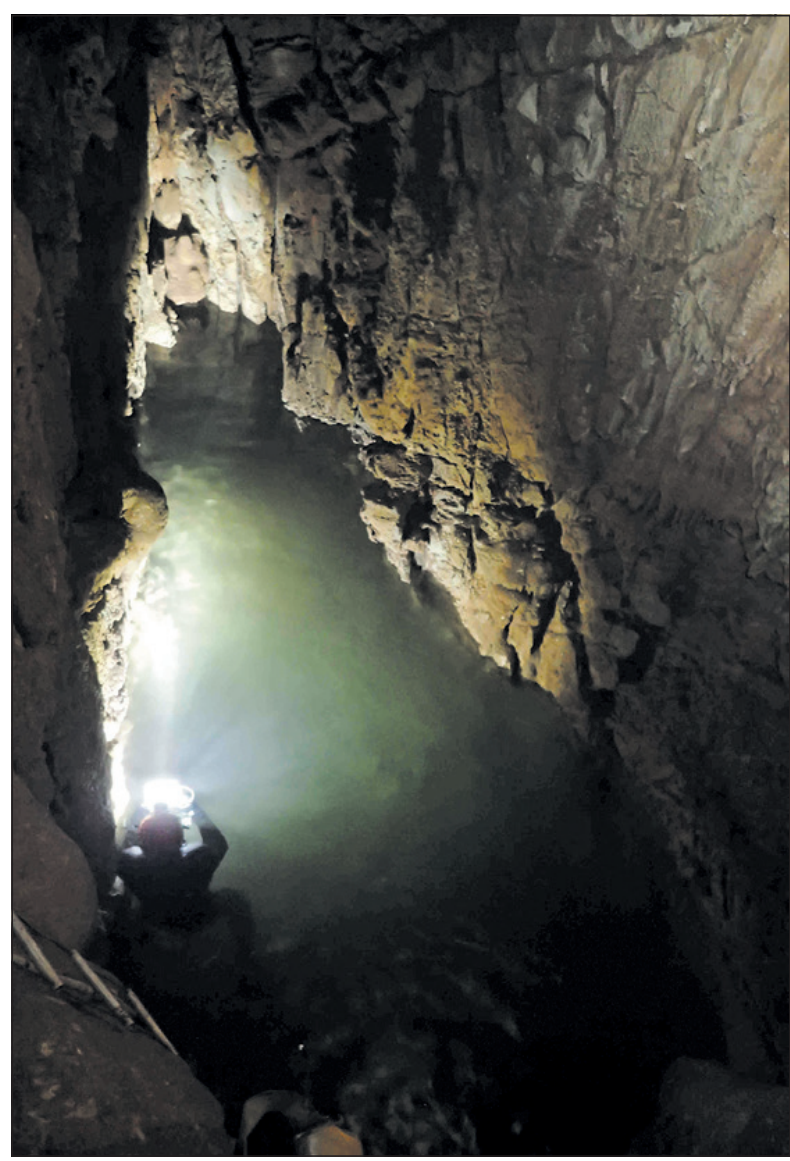

Fig. 6: The bottom of the shaft, extended on a joint of set $j 1$. Note the limestone of the Repen formation (Cenomanian-Turonian) with decimetric stratification where a thicker and more compact layer is intercalated. The piezometric level of groundwater is about 1.89 $m$ a.s.l. (Photo: S. Rejc).

quote (about $4 \mathrm{~m}$ a.s.l.), only $19 \mathrm{~m}$ lower than that of Pozzo dei Protei di Monfalcone.

In this study, the sea level variations data measured at Panzano Bay marigraph (regional Id code: P004) have been considered.

\section{RESULTS OF MONITORING}

The data recorded by the Baro-Diver probe and the CTDDiver probe are shown in Figs. 7-9.

During the monitoring period in the Pozzo dei Protei di Monfalcone the water level fluctuated between 1.73 $\mathrm{m}$ a.s.l. and $2.32 \mathrm{~m}$ a.s.l. (average level $1.89 \mathrm{~m}$ a.s.l.).

Cumulative rainfall in the monitoring period was
$270.4 \mathrm{~mm}$, while mean air temperature in Monfalcone area was $24.6^{\circ} \mathrm{C}$. Between 31/08/2018 and 01/09/2019 a moderate rainfall occurred with a cumulative precipitation of $58.4 \mathrm{~mm}$ (Fig. 7).

Mean daily Isonzo River discharge in the monitor- 


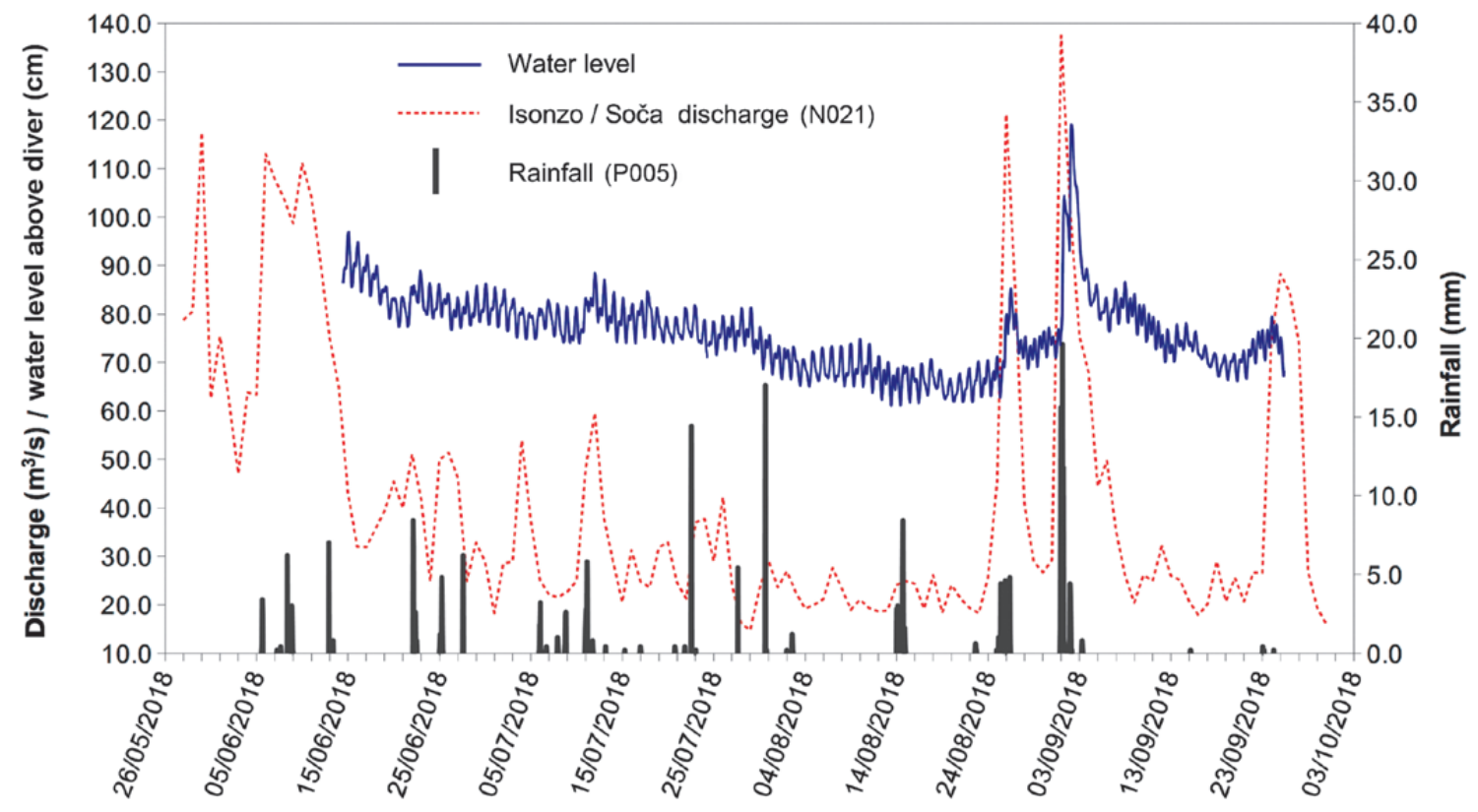

Fig. 7: Comparison between water level in the shaft, precipitation on the western part of Classical Karst (R001) and the flow of the Isonzo River measured at the Piuma bridge (N021).

ing period was about $34 \mathrm{~m}^{3} / \mathrm{s}$, with a maximum value of $137.4 \mathrm{~m}^{3} / \mathrm{s}$ measured on 01/09/2018 (Fig. 7).

Excluding the changes in level caused by tidal oscillations and by an increase in the discharge of the Isonzo River, a decrease in the level of water in the cave was observed (Fig. 7).

The electrical conductivity $\left(\mathrm{EC}, \mathrm{K}_{25}\right.$ ) fluctuated between 336 and $387 \mu \mathrm{S} / \mathrm{cm}$ (average $348 \mu \mathrm{S} / \mathrm{cm}$ ), while the water temperature varied between $12.16^{\circ} \mathrm{C}$ and $12.71^{\circ} \mathrm{C}$ (average temperature $12.41^{\circ} \mathrm{C}$ ) (Figs. 8-9).

As known for the western part of the hydrostructure (Civita et al. 1995; Flora \& Longinelli 1989; Doctor et al. 2006), the level fluctuations observed in the cave are the result of several factors: the allogenic recharge by losses of the Isonzo River inside the Karst and autogenic recharge due to precipitation and consequently to the diffuse infiltration. The average contribution of Isonzo River to the aquifer recharge has been quantified in 10 $\mathrm{m}^{3} / \mathrm{s}$ (Urbanc et al. 2012; Calligaris et al. 2019a).

Level oscillations with periods between 11 and 13 hours have been observed in the Pozzo dei Protei di Monfalcone. The maximum daily excursion is included between $10-12 \mathrm{~cm}$ and 5-6 $\mathrm{cm}$ and occurs respectively during spring tides and neap tides when the variations in sea level in the Panzano Bay are about $130 \mathrm{~cm}$ and 50-60 $\mathrm{cm}$ respectively (Fig. 10). The variations in the cave water level reflect the trend of the astronomical tide that in the neap is diurnal (a single high and low tide per day) while on the occasion of the full moons and new moons it is semidiurnal (two high and two low tides at the day with period of about $12 \mathrm{~h}$ ) (Fig. 11). The lag between the height of the tide and the maximum water level reached in the cave is about $4-4.5 \mathrm{~h}$. This phase shift is mainly due to the characteristics of the aquifer and the fact that it comes in contact with the sea at the system's springs (among which we remember the numerous coastal springs) and indirectly through the gravelly, sandy and silty Quaternary unconsolidated sediments of alluvial and marine origin. Tidal propagation is affected by head losses occurring at the interface with the Adriatic Sea and inside the aquifer causing a damping (decrease in signal amplitude) and a lag. The sea level oscillations also influence the observed shape of flood hydrograph, going to decrease or increase the emptying speed of the groundwater system due to the increase or decrease of the hydraulic gradient due to low and high tides respectively.

The mean EC $(348 \mu \mathrm{S} / \mathrm{cm})$ in the monitoring period is slightly higher (about $30 \mu \mathrm{S} / \mathrm{cm}$ ) than those measured in the Doberdò Lake, and comparable with those of the Cavernetta presso Comarie (1287/VG4221) and the Sablici Canal and the Moschenizze Nord Springs (Grillo 2012).

The EC $\left(\mathrm{K}_{25}\right)$ of the phreatic water of three wells in the alluvial aquifer NE of Monfalcone is between 443 and $463 \mu \mathrm{S} / \mathrm{cm}$ (Gerdol 2013) in clear contrast to the karstic aquifer. 
Analyzing the trend of EC over time, an increase about $51 \mu \mathrm{S} / \mathrm{cm}$ was observed, around $23 / 24 \mathrm{~h}$ after the maximum level determined by flow increase of the Isonzo River and by precipitation. This is an index of mobilization of more mineralized waters.

We also observed variations in the EC, $4-5 \mu \mathrm{S} / \mathrm{cm}$ near the spring tides and $2-3 \mu \mathrm{S} / \mathrm{cm}$ near the neap tides, with a sinusoidal pattern, and a period comparable to that of the tides (between 11 and $14 \mathrm{~h}$ ), but with a lag of $6.5 \mathrm{~h}$ respect to the increase of the water level in the cave due to the tide (Fig. 12).

It is excluded that the cave is directly affected by a saltwater wedge, in fact, the average altitude of piezometric level in the period considered was $1.89 \mathrm{~m}$ a.s.l. and the bottom of cave is about $-0.52 \mathrm{~m}$ below s.l.. The saltwater wedge, given the greater density of seawater than

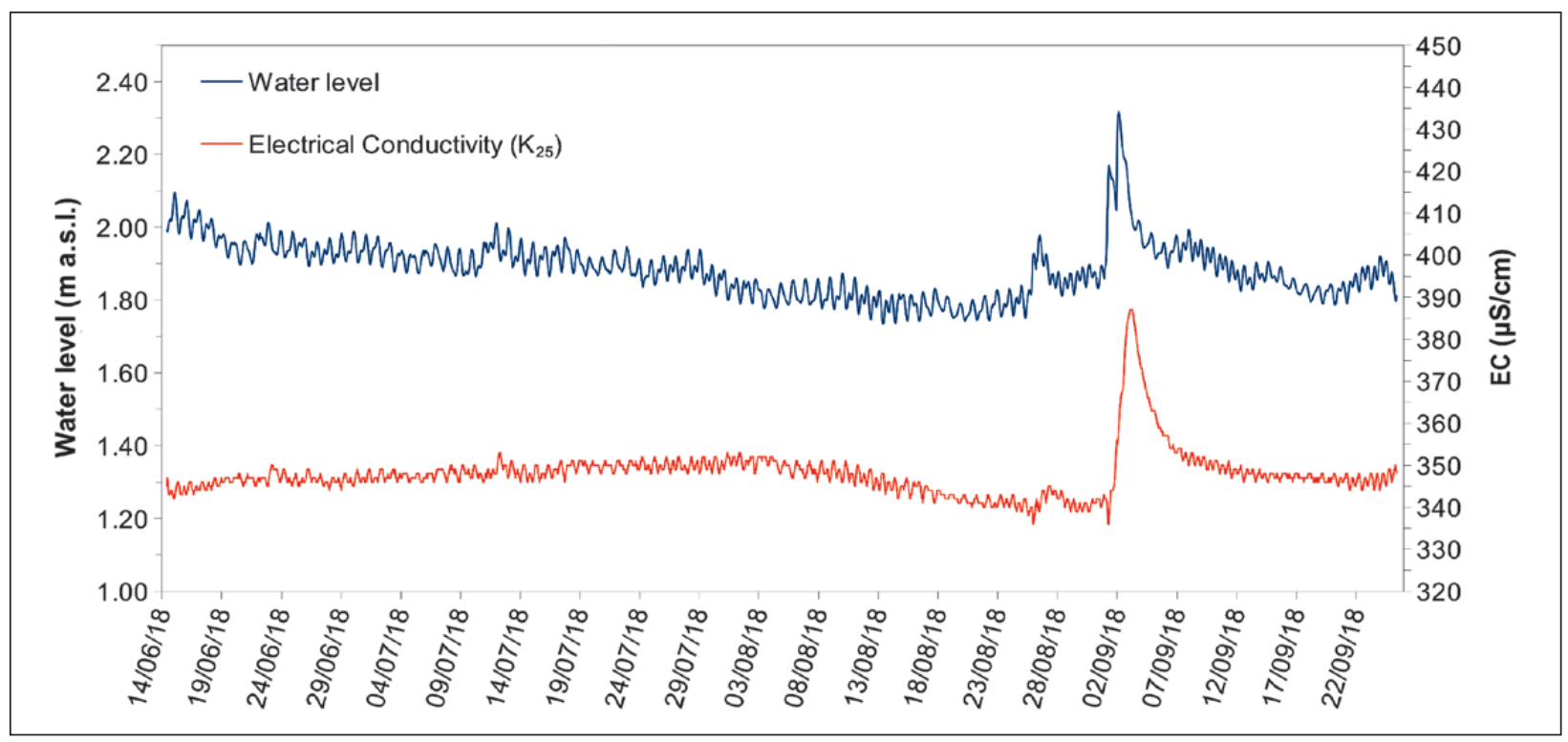

Fig. 8: Comparison between the water level oscillations and EC $\left(K_{25}\right)$ fluctuations in the shaft.

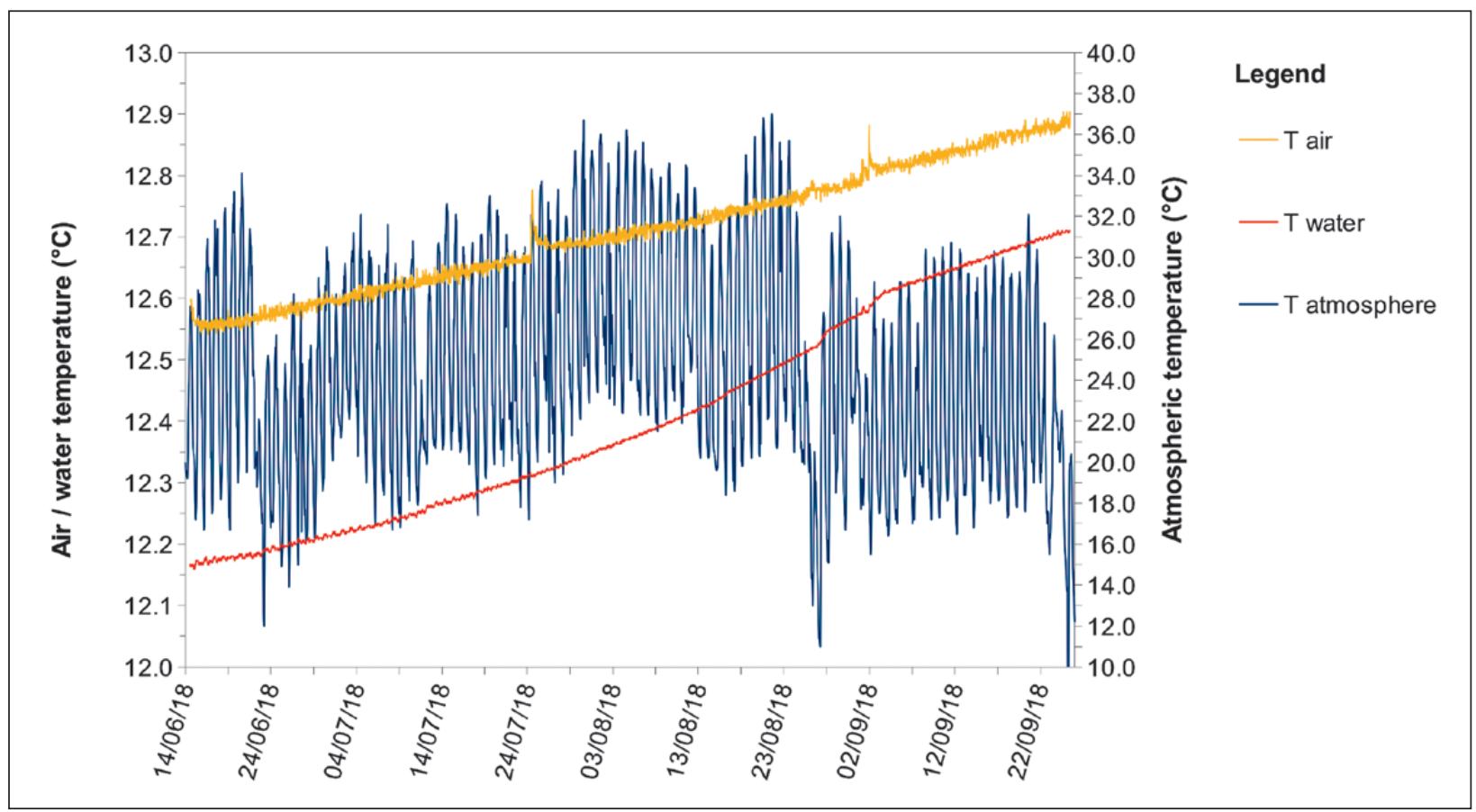

Fig. 9: Comparison between atmospheric temperature measured at "Monfalcone city pool station" (P005) and air and water temperatures in the shaft. 
freshwater, should be deeper as can be demonstrated using simplified methods like Ghyben - Herzberg equation (Barlow 2016). An electrical conductivity log carried out by lowering the CTD-Diver probe to the bottom of the cave did not show any stratification of the water.

The cyclical variations of EC observed could be due to the entry into the cave of waters with greater mineralization coming from the joints of rock mass or from the karstic conduit discovered at the bottom, mobilized by the increase and release of head loss caused by the high tides. It is considered probable the presence of a saltwater wedge in depth in the saturated zone and of a dispersion zone at the interface between fresh and salt water where, due to the concentration gradient, the solutes move from the areas with higher concentration (salt and brackish water) to those where the concentration is lower (fresh-

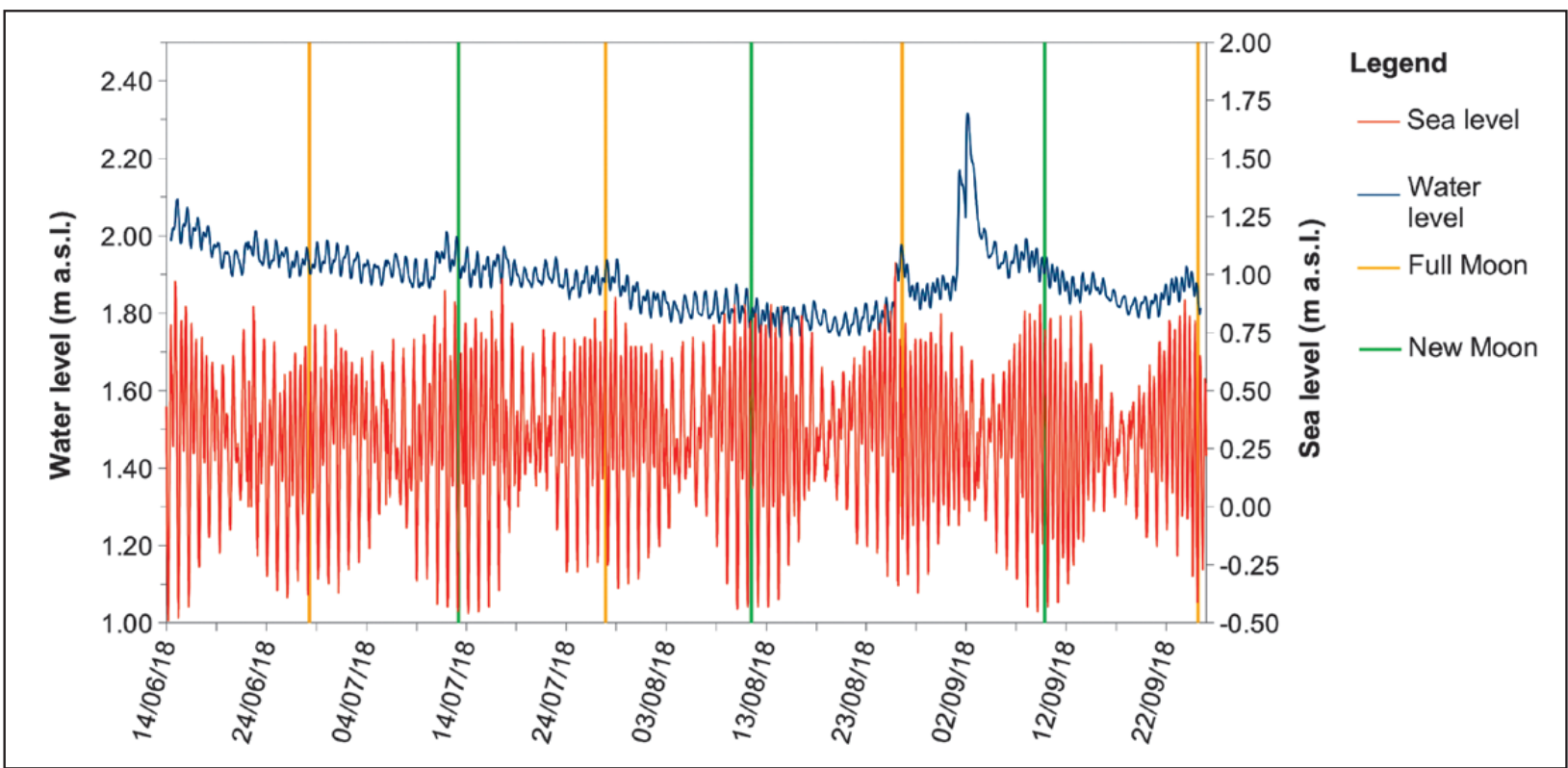

Fig. 10: Comparison between the water level in the shaft and the level of the Adriatic Sea measured in the Panzano Bay.

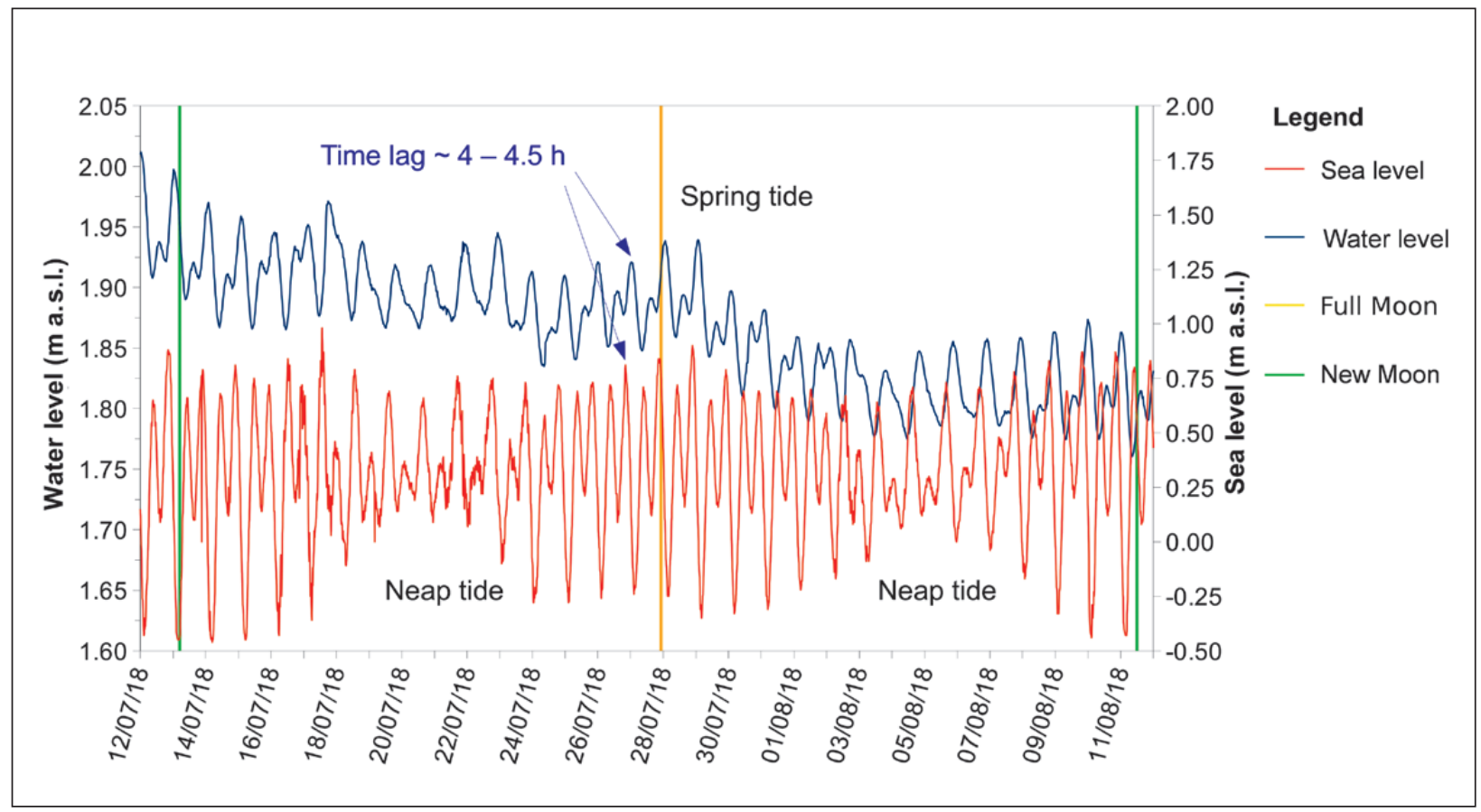

Fig. 11: Comparison between tidal oscillations in the synodic month and fluctuations in the water level of the shaft. 
water). The position of the interface between fresh water and the amplitude of the dispersion zone would be influenced by the water head variations in the aquifer, due to surface recharge, and by the amplitude of the tidal oscillations.

The hypothesis of a phenomenon of marine ingression in the karstic aquifer and/or of contributions from saline fossil waters and of mixing phenomena between freshwater and saltwater was hypothesized by Gemiti (2011) to justify the excess of chloride ion (chemical species with conservative behavior) resulting from the mass balance made considering the concentrations of this anion in the aquifer. According to this author, this phenomenon justifies the high concentration of chloride ion in the Pozzo presso la 4512 VG (4508/VG5467) which is about 2,500 m ESE from the Pozzo dei Protei di Monfalcone, where the water level is about $1 \mathrm{~m}$ a.s.l. (Saurin et al. 1992). Pelizzari (1994) for the water of this cave mentions average $7.8 \mathrm{mg} / \mathrm{L}$ chlorides, while in previous analyzes Cancian (1988) found chloride concentrations of $23.6-37.2 \mathrm{mg} / \mathrm{L}$. Also the water wells drilled in the limestone that make up the bedrock in the coastal Lisert area have high concentrations of chlorides (Gemiti 2011). In caves that intercept the groundwater about $1.5-2 \mathrm{~km} \mathrm{~N}$ of the Pozzo presso la 4512 VG (4508/VG5467), that is the Grotta Andrea (2391/4804 VG), the Pozzo presso Jamiano (273/VG360) and the Cavernetta presso Comarie (1287/VG4221), chlorides are lower, around 3-4.2 $\mathrm{mg} / \mathrm{L}$ (Bordon et al. 1988). The data on chlorides in the mentioned caves have been confirmed by further chemical analyzes (Federazione Speleologica Isontina 2011). During floods, Klaričìs B4 pumping well shows a completely different behavior from the other points of area
(Calligaris et al. 2018). In fact, in this well an increase of chlorides $\left(\mathrm{Cl}^{-}\right.$max $\left.60 \mathrm{mg} / \mathrm{L}\right)$ and sodium $\left(\mathrm{Na}^{+} \max \right.$ $32 \mathrm{mg} / \mathrm{L}$ ) concentrations was observed that suggests, according to these authors, perhaps fossil marine waters coming from the deep carbonate reservoir like those of nearby Monfalcone thermal springs.

The influence of precipitations, saltwater intrusion and Isonzo River discharge variations on cave water characteristics are not distinguishable without chemical or isotopic analysis (Flora \& Longinelli 1989; Doctor et al. 2006) even if results of researches on groundwater Electrical Conductivity in the area (Calligaris et al. $2019 b$ ) suggests that Isonzo River contribute in low flow conditions could be about 70-75\%. From Fig. 10 it could be noticed that amount of precipitation is often not proportional with Isonzo River discharge, this could be due to the distance between the meteorological monitoring point (R001) and the Isonzo/Soča mountain basin, that is about $1800 \mathrm{~km}^{2}$ wide. Isonzo River water discharge at Piuma bridge (Gorizia), hydrometer (Fig. 1) is in fact affected by rainfalls on mountain basin, spring snow melt and by Solkan hydropower plant located few kilometers upward (Fig. 1), that causes rapid discharge variations.

A damping effect on autogenic input, could be due to the retention of moderate rainfalls by the epikarst (Klimchouk 2004) and by evapotranspiration that on the Classical Karst plateau varies between 450 and $750 \mathrm{~mm} / \mathrm{y}$ (Civita et al. 1995)

There is no information about the relationships between changes of groundwater table levels in Monfalcone Plain and cave water levels, in fact there are no measurements point of the regional monitoring network in the area that can allow comparisons.

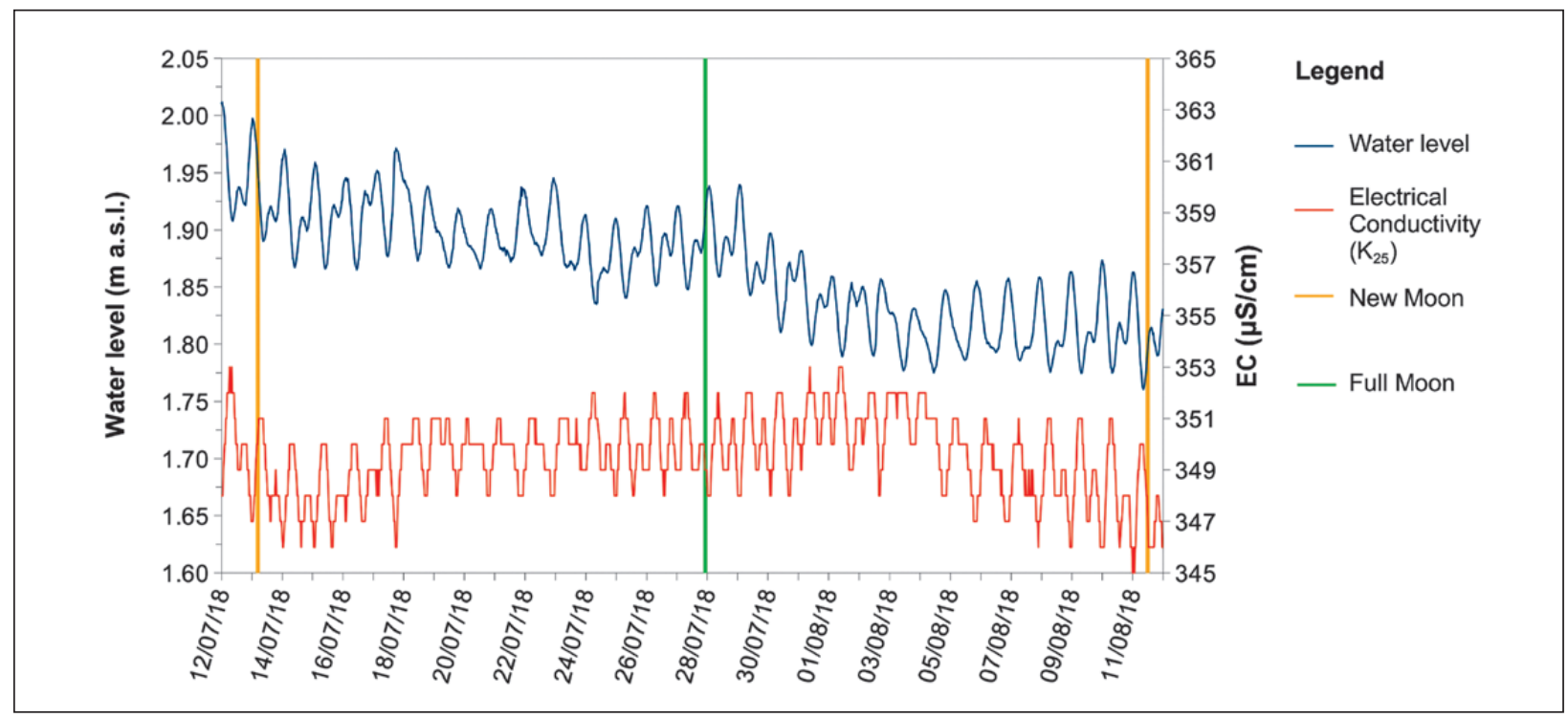

Fig. 12: Comparison between the variations of the level and the conductivity of the groundwater in the shaft during the synodic month. 


\section{CONCLUSIONS}

The edge of the north-western Classical Karst and the carbonate bedrock buried by alluvial and marine sediments, located between the Timavo Springs and the Isonzo River, are very karstified. The current knowledge of this rocky mass of the carbonate edge of the Karst shows small shafts and conduits, attributable to a mixed phreatic and vadose speleogenesis, invaded by the karst groundwater with the piezometric surface located just above the level of Adriatic Sea. The case of the Pozzo dei Protei di Monfalcone with a water table altitude of 1.89 $\mathrm{m}$ a.s.l., which deepens below sea level, exemplifies these characteristics.

The monitoring of the water basin of this shaft has shown that the variations in the hydrometric height and the EC $\left(\mathrm{K}_{25}\right)$ are directly affected by tides of the northern Adriatic Sea, by the allogenic recharge of the Isonzo Riv- er aquifer during flood, and by the autogenic recharge. Water temperature seems instead related to a seasonal trend. In particular daily groundwater level fluctuations range from 5 to $12 \mathrm{~cm}$, and has been correlated to the tides with lag of 4-4.5 h. EC show variations between 2 and $5 \mu \mathrm{S} / \mathrm{cm}$, according to the entity of sea level oscillations. During an allogenic and autogenic recharge (phreatic groundwater of Isonzo River and precipitation) the measured increase of EC was $51 \mu \mathrm{S} / \mathrm{cm}$ with 1 day of lag respect to the hydrological event peaking.

A twofold influence has therefore been observed in the karst aquifer. The first is due to the daily sea level variations of the Panzano Bay. The second corresponds to the periodic allogenic and autogenic variations of recharge due to the floods of Isonzo River and to the local precipitations on the karst plateau.

\section{ACKNOWLEDGEMENTS}

The authors would like to acknowledge CaRiGo - Gorizia Foundation for the contribution to the research costs; the Hydrographic bureau of Regione Autonoma F.V.G. and Ivano Di Fant for the meteorological and hydrographic data; the speleologists Eduardo Klassen, Mauro Pincin, Stefano Rejc, Michele Soranzo (Centre for Karst Researches "C. Seppenhofer") for their collaboration in cave and topographic survey; Luciano Russo for the underwater survey in cave; Graziano Cancian, Fulvio Iadarola, and Mario Galli for the availability of geological and hydrological data of the area; Gian Domenico Cella for the useful discussion; Selli Coradazzi for the collaboration in figures' preparation. Finally we thank the reviewers for their comments and suggestions.

\section{REFERENCES}

Ballarin, L., D’Amelio, L., Forti, Fu., Gentili, V., Piselli, S., Raponi, A., Semeraro, R. \& R. Vanon, 2000a: The karstic aquifer in the region of the "Carso": review of hydrogeology and geochemistry.- Ipogea, 3, 13-32.

Ballarin, L., D’Amelio, L., Krokos, A., Serra, F. \& R. Semeraro, 2000b: Trieste Karst aquifer: review of hydrogeology and geochemistry.- In: Petrič, M \& J. Kogovšek (eds.) COST Action 621 "Groundwater management of coastal karstic aquifers", $7^{\text {th }}$ Management Committee and Working Groups Meeting, Guide-Booklet for the excursion, 23 $3^{\text {th }}-25^{\text {th }}$ March 2000, Postojna. Karst Research Institute, 20, Postojna.

Barlow, P.M., 2016: Ground Water in Freshwater-Saltwater environments of the Atlantic Coast.- U.S. Department of the Interior, U.S. Geological Survey, Cir- cular 1263, U.S Geological Survey, 2003, pp. 113, Reston, Virginia.

Bidovec, F., 1965: The hydrosystem of karstic springs in the Timavo Basin.- Actes Colloque Dubrovnik, AIHS-UNESCO, 1, 26-274.

Boegan, E., 1938: Il Timavo. Studio sull'idrografia carsica subaerea e sotterranea.- Memorie dell'Istituto Italiano di Speleologia, serie Geologica e Geofisica, 2, 1-251.

Bordon, V., Cancian, G. \& D. Pintar, 1988: Ricerche sull'idrologia sotterranea tra il Lago di Doberdò e la Grotta di Comarie (Carso Goriziano) tramite traccianti naturali.- Atti del Museo Civico di Storia Naturale di Trieste, 41, 2, 169-179.

Busetti, M., Volpe, V., Barison, E., Giustiniani, M., Marchi, M., Ramella, R. \& C. Zanolla, 2010a: Ceno- 
zoìc seismic stratigraphy and tectonic evolution of the Gulf of Trieste (Northern Adriatic).- Proceedings of the "ADRIA 2006 - International Geological Congress on Adriatic Area", Urbino (Italy), May 1920, Geo-Acta, Special Publication, 3, 15-28.

Busetti, M., Volpi, V., Nicolich, R., Barison, E., Romeo, R., Baradello, L., Brancatelli, G., Giustiniani, M., Marchi, M., Zanolla, C., Wardell, N., Nieto, D. \& R. Ramella, 201ob: Dinaric tectonic features in the Gulf of Trieste (northern Adriatic Sea).- Bollettino di Geofisica Teorica ed Applicata, 51, 2-3, 117-128.

Calligaris, C., Zini, L. \& F. Cucchi, 2017: Il Lacus Timavi, geologia e geomorfologia.- Atti e Memorie della Commissione Grotte “E. Boegan”, 47, 43-61.

Calligaris, C., Mezga, K., Slejko, F.F., Urbanc, J. \& L. Zini, 2018: Groundwater Characterization by Means of Conservative $\left(\delta^{18} \mathrm{O}\right.$ and $\left.\delta^{2} \mathrm{H}\right)$ and Non-Conservative $\left({ }^{87} \mathrm{Sr} /{ }^{86} \mathrm{Sr}\right)$ Isotopic Values: The Classical Karst Region Aquifer Case (Italy-Slovenia).- Geosciences 2018, 8, 9, 321. https://doi.org/10.3390/geosciences 8090321

Calligaris, C., Casagrande, G., Iervolino, D., Lippi, F., Olivo, P., Ramani, M., Treu, F. \& L. Zini, 2019a: Waterbudget as a tool to evaluate the sustainable use of groundwater resources (Isonzo Plain, NE Italy).Rendiconti Online Societa Geologica Italiana, 47, 7-12. https://doi.org/10.3301/ROL.2019.02

Calligaris, C., Galli, M., Gemiti, F., Piselli, S., Tentor, M., Zini, L. \& F. Cucchi, 2019b: Electrical Conductivity as a tool to evaluate the various recharges of a Karst aquifer.- Rendiconti Online Societa Geologica Italiana, 47, 13-17. https://doi.org/10.3301/ROL.2019.03

Cancian, G., 1976: Il Carso monfalconese: litostratigrafia, tettonica, speleomorfologia e speleogenesi.- Le Grotte d'Italia, rivista dell'Istituto Italiano di Speleologia, a.3, 5/1974-75, 5-30.

Cancian, G., 1988: L'idrologia del Carso goriziano-triestino tra l'Isonzo e le risorgive del Timavo.- Studi Trentini di Scienze Naturali, 64, 77-98.

Carulli, G.B., 2011: Structural model of the Trieste Gulf: A proposal.- Journal of Geodynamics, 51, 2-3, 156165. https://doi.org/10.1016/j.jog.2010.05.004

Cavanna, M., 2018: Isonzo sotterraneo: vulnerabilità ambientale delle aree di studio.- In: Federazione Speleologica Isontina Giornata dedicata agli studi sul carsismo della Regione Friuli Venezia Giulia dai gruppi speleologici dell'isontino, $15^{\text {th }}$ December 2018, Gorizia. Oral presentation (unpublished).

Civita, M., Cucchi, F., Eusebio, A., Garavoglia, S., Maranzana, F. \& B. Vigna, 1995: The Timavo hydrogeologic system: an important reservoir of supplementary water resources to be reclaimed and protected.Acta carsologica, 24, 169-186.
Collignon, B., 2019: Earth Tide Effect in Karstic and Nonkarstic Aquifers in the Guinea Gulf.- In: C. Bertrand et al. (eds.) Eurokarst 2018, Besançon, Advances in Karst Science, Springer Nature Switzerland AG, pp. 233-242, Cham. https://doi.org/10.1007/978-3-03014015-1

Cotecchia, V. \& M. Scuro, 2010: Portrait of a Coastal Karst Aquifer: the City of Bari.- AQUA mundi, Am02021, 187-196. https://doi.org/10.4409/Am-023-10-0021

Cucchi, F., Marinetti, E. \& L. Zini, 1998: Monitoraggio in continuo delle acque carsiche presso le sorgenti del Livenza e del Timavo.- Atti del Convegno nazionale sull'inquinamento delle grotte e degli acquiferi carsici e possibili ricadute sulla collettività, Ponte di Brenta, 63-72.

Cucchi, F., Zini, L., Calligaris, C., Turpaud, Ph., Slejko, F.F., Treu, F., Furlan, I.S., Zavagno, E., Biolchi, S., Michelini, M., Boccali, C., Cleva, S., Urbanc, J., Ferjan Stanič, T., Kogovsek, J., Petrič, M., Gabrovšek, F., Ravbar, N., Altran, E., Piselli, S., Sciolis, D., Sossi, S., Leban, M., Casagrande, G., Brancelj, A. \& N. Mori, 2014: Hydrokarst's role in the knowledge of the Classical Karst aquifer's hydrodynamic (NE Italy, SW Slovenia).- In: Kukurić, N. et al. (eds.) International Conference and Field Seminar "Karst Without Boundaries", $11^{\text {th }}-15^{\text {th }}$ June 2014, Trebinje, Dubrovnik. Grafokomerc, 111-117, Trebinje.

Cucchi, F., Zini, L. \& C. Calligaris, 2015: Le acque del Carso Classico / Vodonosnik Klasičnega Krasa. Progetto / Project Hydrokarst.- Edizioni Università di Trieste EUT, pp. 194, Trieste.

Cucchi, F., Forti, P., Marinetti, E. \& L. Zini, 2000a: Recent developments in knowledge of the hydrogeology of the Classical Karst-. Acta carsologica, 29, 1, 55-78.

Cucchi, F., Furlani, S. \& E. Marinetti, 2000b: Monitoraggio in continuo del livello del Lago di Doberdò.- Atti e Memorie Commissione Grotte "E. Boegan", 37, 143-153.

Cuello, J., Guarracino, L. \& L.B. Monachesi, 2017: Groundwater response to tidal fluctuations in wedge-shaped confined aquifers.- Hydrogeology Journal, 25, 5, 1509-1515. https://doi.org/10.1007/ s10040-017-1579-z

Degrassi, V., 2017: Ipotesi sui limiti occidentali del Lacus Timavi (Mart, Ep. IV, 25). "...et tu ledaeo felix Aquileia Timavo...”.- Atti e Memorie della Commissione Grotte "E. Boegan", 47, 3-24.

Doctor, D.H., Alexander, E.C. Jr., Petrič, M., Kogovšek, J., Urbanc, J., Lojen, S. \& W. Stichler, 2006: Quantification of karst aquifer discharge component through end-member mixing analysis using natural chemistry and stable isotopes as tracers.- Hydrogeol- 
ogy Journal, 13, 1171-1191. https://doi.org/10.1007/ s10040-006-0031-6

Drogue, C., Razack, M. \& P. Krivic, 1984: Survey of a Coastal Karstic Aquifer by Analysis of the Effect of the Sea-tide: Example of the Kras of Slovenia (Yugoslavia).- Environmental Geology Water Sciences, 6, 2, 103-109.

Federazione Speleologica Isontina, 2011: Monitoraggio delle acque ipogee e di superficie del Carso isontino 2009-2011.- Editore Federazione Speleologica Isontina, pp. 126, Gorizia.

Flora, O. \& A. Longinelli, 1989: Stable isotope hydrology of Classical Karst area, Trieste, Italy.- International Atomic Energy Agency Advisory Group Meeting on the application of isotope techniques in the study of the hydrology of fracturated and fissurated rocks. $17^{\text {th }}-21^{\text {th }}$ November 1986, Wien. International Atomic Energy Agency, 203-213, Wien.

Gemiti, F., 2011: Origine e bilancio dei cloruri nelle acque del Carso Classico.- Atti e Memorie della Commissione Grotte "E. Boegan", 43, 117-149.

Gemiti, F. \& M. Licciardello, 1977: Indagine sui rapporti di alimentazione delle acque del Carso triestino e goriziano mediante l'utilizzo di alcuni traccianti naturali.- Annali del Gruppo Grotte dell'Associazione XXX Ottobre, 6, 43-61.

Gerdol, C., 2013: Idrogeologia della Piana Isontina (ITASLO).- Master degree thesis, University of Padova, pp. 308.

Grillo, B., 2012: Ricostruzione dell'idrodinamica delle acque di falda del Carso Classico.- PhD Thesis, University of Trieste, pp. 355.

Iadarola F., 1996: Studio Geologico per il P.R.G.C. di Monfalcone.- Municipality of Monfalcone, Internal Report (unpublished).

Jurkovšek, B., Toman, M., Ogorelec, B., Sribar, L., Drobne, K., Poljak, M. \& L. Sribar, 1996: Formacijska geološka karta južnega dela Tržasko-Komenske planote. Kredne in paleogenske karbonatne kamnine, 1:50.000.- Ljubljana.

Jurkovšek, B., Biolchi, S., Furlani, S., Kolar-Jurkovšek, T., Zini, L., Jež, J., Tunis, G., Bavec, M. \& F. Cucchi, 2016: Geology of the Classical Karst Region (SW Slovenia - NE Italy).- Journal of Maps, 12, S1, 352-362. http://doi.org/10.1080/17445647. 2016.1215941

Klimchouk, A., 2004: Towards defining, delimiting and classifying epikarst: Its origin, processes and variants of geomorphic evolution.- Speleogenesis and Evolution of karst aquifers, 2, 1, 1-13.

Krivic, P., 1982a: Variations naturelles de niveau piézométrique d'un aquifère karstique.- Geologija, 25, 1, 129-150.

Krivic, P., 1982b: Transmission des ondes de marée a tra- vers l'aquifère côtier de Kras.- Geologija, 25, 2, 309325.

Marocco R., \& R. Melis, 2009: Stratigrafia e paleogeografia del "Lacus Timavi" (Friuli Venezia Giulia).- Il Quaternario, Italian Journal of Quaternary Sciences, 22, 2, 157-170.

Martinis, B., 1962: Ricerche geologiche e paleontologiche sulla regione compresa tra il fiume Judrio ed il fiume Timavo (Friuli orientale).- Rivista Italiana di Paleontologia e Stratigrafia, 8, pp. 1-244.

Martinis, B., 1975: Indagini geologiche e geotecniche effettuate sull'altopiano di Doberdò (Gorizia) per il progettato protosincrotrone Europeo da $300 \mathrm{GeV}$ del CERN.- Memorie dell'Istituto di Geologia e Mineralogia dell'Università di Padova, 31, 1-78.

Masoli, M, \& G. Spangher, 1977: Alcuni aspetti geotettonici di dettaglio del Carso Goriziano (Gorizia).- Atti e Memorie della Commissione Grotte "E. Boegan", $16,105-116$.

Menchini, G., 2016: Studio di Microzonazione Sismica del territorio comunale di Monfalcone, Livello 1.- $\mathrm{Mu}$ nicipality of Monfalcone, Internal Report (unpublished).

Merlak, E., 1972: Ricerche geologiche nella zona carsica di San Giovanni al Timavo (Carso Triestino nord-occidentale).- Annali del Gruppo Grotte dell'Associazione XXX Ottobre, CAI Trieste, 5, 1546.

Mosetti, F., 1957: Prospezione geoelettrica per la cartiera del Timavo. Un caso di applicazione della geofisica a problemi di fondazione.- Tecnica Italiana, 12, 4, 3-7. Nicolettis, P., 1983: Il regime idrico del Lago di Doberdò e della falda carsica del monfalconese.- Atti del $4^{\circ}$ Convegno di Speleologia del Friuli Venezia Giulia, Pordenone 1979, 249-256.

Nicolich, R., Della Vedova, B., Giustiniani, M. \& R. Fantoni, 2004: Carta del sottosuolo della Pianura Friulana, Note illustrative.- Regione Autonoma Friuli Venezia Giulia, Direzione centrale ambiente e lavori pubblici, Servizio geologico and Università degli Studi di Trieste, Dipartimento di Ingegneria, Civile Sezione Georisorse e Ambiente, pp. 32, Trieste.

OSMER FVG, 2019a: Elaborazioni decadali piogge cumulate 2006-2019.- [Online] Available from: https://www.osmer.fvg.it/clima/clima_fvg/01_elaborazioni_(grafici_e_tabelle)/01_precipitazioni/ dati_elaborati/dati_rete_micros_dal_1990/tabelle_per_stazione/02_piogge\%20giornaliere/decadali/01_piogge_cumulate/MONFALCONED_RR_. pdf [Accessed 13th November 2019].

OSMER FVG, 2019b: Elaborazioni decadali media della temperatura media dell'aria giornaliera 2006-2019.[Online] Available from: https://www.osmer.fvg. 
it/clima/clima_fvg/01_elaborazioni_(grafici_e_tabelle)/03_temperatura_aria_a_180_cm/dati_elaborati/dati_rete_micros_dal_1990/tabelle_per_ stazione/decadali/02_temperatura_media_giornaliera/05_media_della_temperatura_media_ dell'aria_giornaliera/MONFALCONED_T18.pdf [Accessed 13th November 2019].

Pellizzari, G., 1994: Studio idrologico delle acque del canale Sablici e della Grotta dello svincolo ferroviario (Carso monfalconese).- Studi e ricerche della Società di studi carsici "Lindner", 1, 92-106.

Petrini, R., Italiano, F., Ponton, M., Slejko, F., Aviani, U. \& L. Zini, 2013: Geochemistry and isotope geochemistry of the Monfalcone thermal waters (northern Italy): inference on the deep geothermal reservoir.Hydrogeology Journal, 21, 6, 1275-1287. https://doi. org/10.1007/s10040-013-1007-y

Placer, L., 2008: Principles of the tectonic subdivision of Slovenia.- Geologija, 51, 2, 205-217. https://doi. org/10.5474/geologija.2008.021

Placer, L., Vrabec, M. \& B. Celarc, 2010: The bases for understanding of the NW Dinarides and Istria Peninsula tectonics.- Geologija, 53, 1, 55-86. https://doi. org/10.5474/geologija.2010.005

Placer, L., 2015: Simplified structural map of Kras; Kras (Slovene), Carso (Italian) = Geographical unit.Geologija, 58, 1, 89-93. https://doi.org/10.5474/geologija.2015.008

Regione Autonoma Friuli Venezia Giulia, 1990: Catasto regionale dei pozzi per acqua delle perforazioni eseguite nelle alluvioni quaternarie e nei depositi sciolti del Friuli Venezia Giulia.- Regione Autonoma Friuli Venezia Giulia, Direzione Regionale Ambiente, Trieste, 7 vol.

Regione Autonoma Friuli Venezia Giulia, Servizio Geologico, 2008: Carta geologica di sintesi alla scala 1:10.000, Sezioni 088150 e 109030.- [Online] Available from: http://www.regione.fvg.it/rafvg/export/ sites/default/RAFVG/ambiente-territorio/tutelaambiente-gestione-risorse-naturali/FOGLIA201/ FOGLIA6/allegati10000/pdf_CGT_sintesi/088150. pdf - ibidem: sintesi/109030.pdf [Accessed 13th November 2019].

Regione Autonoma Friuli Venezia Giulia, 2019: WebGIS. Regione Autonoma FVG.- [Online] Available from: http://irdat.regione.fvg.it/WebGIS/GISViewer.jsp?template $=$ configs $\% 3$ AIdraulica $\% 2$ Fidrauli ca.xml\&UrlUOI=http\%3A\%2F\%2Fasr-str01.regione.fvg.it\%3A80\%2FPubblicazioneUOI\&UOISession $=1 \mathrm{~b} 36 \mathrm{bc738b} 55 \mathrm{a} 8 \mathrm{fd} 9 \mathrm{e} 7031 \mathrm{cdfb} 60 \mathrm{cf} 34878 \mathrm{e}$
8d9db72929a0f007b3c37a4c5cfc.e34SaNaLbhiRa4 0LbxyKah4Kch0Ne0\&GisServer=http\%3A\%2F\%2 Firdat.regione.fvg.it\%2FWebGIS\&TOKEN $=\quad[$ Accessed 13th November 2019].

Rejc, S., 2018: Conclusa la campagna del "Progetto idrogeologico Pozzo dei Protei”: dall'acquisizione dei dati idrogeologici mediante monitoraggio in continuo all'ispezione subacquea e ai rilievi in cavità.Sopra e sotto il Carso, Notiziario online del CRC "C. Seppenhofer", 7, 10, 12-14.

Russo, L., 2018: Relazione sullispezione subacquea al Pozzo dei Protei di Monfalcone (GO) VG 4383/5403 del 13 ottobre 2018.- Rapporto e rilievo topografico (unpublished).

Samez, D., Casagrande, G., Cucchi, F. \& L. Zini, 2005: Idrodinamica dei laghi di Doberdò e di Pietrarossa (Carso Classico, Italia). Relazioni con le piene dei fiumi Isonzo, Vipacco e Timavo.- Atti e Memorie Commissione Grotte "E. Boegan", 40, 13-52.

Semeraro, R. \& F. Valentinuz, 2018: Monitoraggio in continuo del Pozzo dei Protei di Monfalcone (Carso Classico).- In: Federazione Speleologica Isontina Giornata dedicata agli studi sul carsismo della Regione Friuli Venezia Giulia dai gruppi speleologici dell'isontino, $15^{\text {th }}$ December 2018, Gorizia. Oral presentation (unpublished).

Stoch, F., 2017: Il Lacus Timavi: la fauna acquatica sotterranea, con particolare riguardo alle risorgive del Fiume Timavo.- Atti e Memorie della Commissione Grotte "E. Boegan", 47, 173-203.

Saurin, E., Marchi, F. \& S. Mantoani, 1992: La Grotta dello svincolo ferroviario 5467 VG.- Studi e ricerche della Società di studi carsici "Lindner", 1, 55-62.

Urbanc, J., Mezga, K. \& L. Zini, 2012: An assessment of capacity of Brestovica - Klariči karst water supply (Slovenia).- Acta carsologica, Postojna, 41, 1, 89100. https://doi.org/10.3986/ac.v41i1.50

Venzo, G.A. \& A. Fuganti, 1965: Analisi strutturale delle deformazioni tettoniche del Carso Goriziano (Gorizia).- Studi Trentini di Scienze Naturali, sez. A, 42, 2, 335-366.

Zamora, P.B., Bayani Cardenas, M., Lloren, R. \& F.P. Siringan, 2017: Seawater-groundwater mixing in and fluxes from coastal sediment overlying discrete fresh seepage zones: A modeling study.- AGU Journal of Geophysical Research: Oceans, 122, 8, 65656582. https://doi.org/10.1002/2017JC012769

Zini, L., Calligaris, C. \& F. Cucchi, 2017: Il Lacus Timavi, idrogeologia.- Atti e Memorie della Commissione Grotte "E. Boegan", 47, 63-76. 